\title{
Dosimetric Comparison of VMAT, IMRT and Proton Therapy for Post- Prostatectomy Radiation Therapy for Prostate Cancer
}

\author{
L. A. Doyle \\ Thomas Jefferson University and Hospitals \\ M. Studenski \\ Thomas Jefferson University and Hospitals
}

A. Harvey

Thomas Jefferson University and Hospitals

A. P. Dicker

Thomas Jefferson University and Hospitals

Y. Xiao

Thomas Jefferson University and Hospitals. Follow this and additional works at: https://jdc.jefferson.edu/bodinejournal

Part of the Oncology Commons

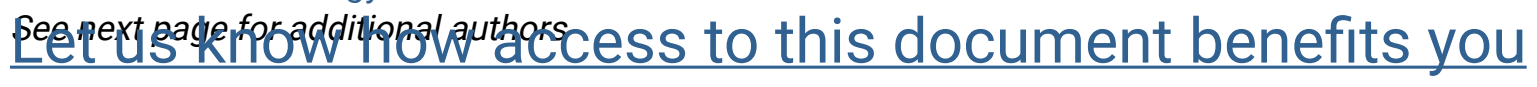

\section{Recommended Citation}

Doyle, L. A.; Studenski, M.; Harvey, A.; Dicker, A. P.; Xiao, Y.; Yu, Y.; Showalter, T. N.; and Harrison, A. (2010) "Dosimetric Comparison of VMAT, IMRT and Proton Therapy for Post- Prostatectomy Radiation Therapy for Prostate Cancer," Bodine Journal: Vol. 3 : Iss. 1 , Article 28.

DOI: https://doi.org/10.29046/TBJ.003.1.027

Available at: https://jdc.jefferson.edu/bodinejournal/vol3/iss1/28

This Article is brought to you for free and open access by the Jefferson Digital Commons. The Jefferson Digital Commons is a service of Thomas Jefferson University's Center for Teaching and Learning (CTL). The Commons is a showcase for Jefferson books and journals, peer-reviewed scholarly publications, unique historical collections from the University archives, and teaching tools. The Jefferson Digital Commons allows researchers and interested readers anywhere in the world to learn about and keep up to date with Jefferson scholarship. This article has been accepted for inclusion in Bodine Journal by an authorized administrator of the Jefferson Digital Commons. For more information, please contact: JeffersonDigitalCommons@jefferson.edu. 


\section{Dosimetric Comparison of VMAT, IMRT and Proton Therapy for Post-}

Prostatectomy Radiation Therapy for Prostate Cancer

\section{Authors}

L. A. Doyle, M. Studenski, A. Harvey, A. P. Dicker, Y. Xiao, Y. Yu, T. N. Showalter, and A. Harrison 


\title{
Dosimetric Comparison of VMAT, IMRT and Proton Therapy for Post- Prostatectomy Radiation Therapy for Prostate Cancer
}

\author{
Doyle, L.A., Studenski, M., Harvey A., Dicker, A.P., Xiao, Y., Yu, Y., Showalter, T.N., Harrison, A. \\ Department of Radiation Oncology, Thomas Jefferson University and Hospitals, Philadelphia, PA
}

\section{Purpose/Objectives}

Radiation therapy (RT) for the treatment of prostate cancer after radical prostatectomy (RP) is widely accepted. With technological advances, radiation treatment technique and dosimetry may vary. The purpose of this study is to quantify dosimetric difference of proton therapy versus VMAT and IMRT focusing on bladder and rectal dose sparing and target coverage.

\section{Materials/Methods}

This study analyzes a subset of twenty patients who received post-RP RT at our institution and builds on initial work comparing 3DRT to IMRT for these patients. All volumes were delineated by a single observer in accordance with EORTC consensus guidelines. A CTV expansion of $7 \mathrm{~mm}$ ( $5 \mathrm{~mm}$ posteriorly) was used to determine the PTV. All plans met a minimum of $95 \%$ target coverage to a prescription dose of $68.4 \mathrm{~Gy}$. Optimal beam arrangement for IMRT was previously studied at our institution, leading to selection of a 9-field technique. The VMAT planning utilized either 1 or 2 full arcs depending upon optimizer performance. The proton arrangement was opposed laterals and utilized active scanning. As this was a strict dosimetric analysis, density corrections were not employed. Five patients were analyzed for this initial study. Differences of DVH values between plans were evaluated using 2-tailed paired t-tests.

\section{Results}

Planning with all three treatment techniques demonstrated comparable PTV coverage. Difference in dose sparing of bladder or rectum between 9-field IMRT and VMAT planning was not significant. Improvement in rectal doses, proton versus VMAT and IMRT was significant when comparing $\mathrm{V}_{40 \mathrm{~Gy}}, \mathrm{~V}_{34.2 \mathrm{~Gy}}$ (28\%, vs $48.16 \%$ and $45.33 \%, p=0.016 \& \mathrm{p}=0.0004)$. Bladder doses showed significance at $\mathrm{V}_{30 \mathrm{~Gy}}, \mathrm{~V}_{17.1 \mathrm{~Gy}}(32.58 \%$ vs $57.27 \%$ \& $62.76 \%, \mathrm{p}=0.045 \& \mathrm{p}=0.04)$. Differences for $V_{D}$ when $D>40 G y$ for rectum and $V_{D}$ when $D>30 G y$ for bladder across all planning techniques were not significant.

\section{Conclusion}

Proton planning resulted in greater sparing of normal tissues at lower doses with equivalent planned target coverage. Further research is necessary to determine the significance of better planned doses with protons compared to photon treatment with regard to toxicity and proven efficacy of photon therapy. The delivery efficiency with VMAT may prove a viable advantage. Cost effectiveness research is necessary to determine if the increased cost of proton therapy is outweighed by benefit to the patient if these dosimetric improvements translate into improved clinical outcomes for PC patients. 